\title{
GRAFICZNY INTERFEJS UŻYTKOWNIKA I FUNKCJONALNOŚĆ WIRTUALNYCH WYCIECZEK NA WYBRANYCH PRZYKŁADACH
}

\author{
AGNIESZKA PILARSKA ${ }^{1}$, PAULINA TOMCZYKOWSKA ${ }^{2}$ \\ ${ }^{1}$ Uniwersytet Mikołaja Kopernika w Toruniu, Wydział Nauk o Ziemi, \\ Katedra Geomatyki i Kartografii, ul. Lwowska 1, 87-100 Toruń, \\ ${ }^{2}$ Uniwersytet Mikołaja Kopernika w Toruniu, Wydział Nauk o Ziemi, \\ Katedra Gospodarki Przestrzennej i Turyzmu, ul. Lwowska 1, 87-100 Toruń
}

\begin{abstract}
The aim of this paper is to characterize the graphical interface and functionality of virtual tour applications. The indirect aim is to provide initial technical assessment of selected virtual tours avaialable on Polish websites. In addition, the article presents the importance of the terms related to multimedia presentation of online tourist content. References have been made to concepts such as geoinformation society, geoinformation, geospatial data, interactive panoramas and tourism space.

In the research, descriptive and comparative methods were used. The initial technical assessment was made by means of the Web Page Analyzer - 0.98 (http://www.websiteoptimization.com/services/analyze) from Website Optimization.

Results

Research into the interface, the functionality and technical assessment revealed that the selected virtual tour applications available online are very diverse. The differences exist both on the quantitative and the qualitative levels.

The results have led to a conclusion that the Internet infrastructure, with special emphasis placed on the geo-information infrastructure, allows to develop and transfer tourist activity to the virtual world. The progressive functionality and ergonomics of the interfaces enable multimedia presentations in the form of virtual tours, including use of $360^{\circ}$ panoramas, to reach an increasingly wide audience with diverse interests.
\end{abstract}

Keywords: virtual sightseeing, $360^{\circ}$ panorama, graphic user interface, technical evaluation of a site, virtual tour.

\section{WSTĘP}

Dostęp do Internetu jest udziałem coraz większej liczby osób na świecie. Szacuje się, że połowa ludzkości aktywnie korzysta z tego medium. Uważa się, że w Polsce w 2017 r. było blisko 26 mln internautów. Średni czas, jaki wówczas Polacy spędzali na przeglądaniu stron internetowych wyniósł około 6 godz. dziennie (Tech Trends, 2017). Biorąc pod uwagę te dane, należy zgodzić się z tym, że Internet oddziałuje na coraz więcej form aktywności ludzkiego życia. Jedną z nich, którą Polacy coraz chętniej i częściej przenoszą do świata wirtualnego, jest turystyka. Jest to niewątpliwie jeden z przejawów narodzin i kształtowania się społeczeństwa geoinformacyjnego (Pilarska 2015). Wskazany rodzaj społeczeństwa wykorzystując usługi infrastruktury geoinformacyjnej, korzysta 
z geoinformacji (Internetowy leksykon geomatyczny, 2011a). Warto w tym miejscu wyjaśnić pojęcie ,geoinformacji”. W świetle literatury przedmiotu geoinformację uzyskuje się na podstawie interpretacji zbioru danych, które mają charakter przestrzenny (czyli danych geoprzestrzennych) (Internetowy leksykon geomatyczny, 2011b). Wskazany w definicji rodzaj danych jest tożsamy z danymi geograficznymi określającymi położenie, czas oraz cechę (atrybut) wyrażoną w skali jakościowej lub ilościowej (Pilarska 2012).

Powszechny i łatwy dostęp do urządzeń łączących się z Internetem sprawił, że ludzie mogą uczestniczyć w nowej formie turystyki. Popularne staje się penetrowanie przestrzeni turystycznej definiowanej jako zbiór obiektów służących zaspokajaniu określonych potrzeb człowieka za pomocą nowoczesnej technologii (Liszewski 2005). Internautom umożliwia się tzw. quasi-eksplorację, która zachodzi przy wykorzystaniu zróżnicowanych form prezentacji danych turystycznych i publikowaniu ich w Internecie. Jedną z form internetowej eksploracji jest zwiedzanie wirtualnych przestrzeni miast dzięki udostępnianym w sieci wirtualnym spacerom, traktowanym w poniższym tekście synonimicznie $\mathrm{z}$ terminem wirtualne wycieczki.

Taka aktywność w globalnej sieci polega na przyswajaniu multimedialnych treści prezentowanych w wysokiej jakości, dzięki czemu użytkownicy mogą zobaczyć dane miejsce w sposób możliwie zbliżony do rzeczywistości. Internauta, za pomocą strzałek kierunkowych lub myszy, może rozglądać się dokoła, podziwiać perspektywę i wybrane detale, zmieniać lokalizacje, przybliżać bądź oddalać widok oraz przemieszczać się w wybranych kierunkach. Celem tej formy prezentacji jest wywoływanie u użytkownika wrażenia przebywania w określonym miejscu (Młynarczyk 2014). Metody wizualnej komunikacji i prezentowania treści rozwijają się systematycznie, dzięki czemu zwiększa się atrakcyjność wirtualnych spacerów. Możliwa staje się trójwymiarowa prezentacja obiektów, która pozwala oddać realistyczny wygląd oglądanego przedmiotu, np. eksponatu muzealnego lub tekstury budynków. Internauta ma możliwość nawigacji w dowolnym czasie, różnej skali i wyboru punktów obserwacji. Tym samym rozbudza się jego zainteresowanie, które w rezultacie może przełożyć się na podjęcie decyzji o wyjeździe w miejsce oglądane w Internecie.

Wywołanie wrażenia realizmu u odbiorcy, z zachowaniem perspektywy, z jednoczesną możliwością jej zmiany, a tym samym podniesienie walorów wirtualnego spaceru jest możliwe dzięki panoramom. Termin ten rozumiany jest jako szerokokątny, rozległy, horyzontalny widok obejmujący całość lub znaczne fragmenty przestrzeni czy prezentacja przestrzeni fizycznej w wielu formach wyrazu, m.in. w malarstwie, rysunku, fotografii (Czyńska 2006).

Jednym z rodzajów prezentacji panoramicznych jest panorama $360^{\circ}$, dzięki której można bardziej szczegółowo i w atrakcyjny sposób zaprezentować obiekt lub miejsce. Przykładem tego typu prezentowania przestrzeni jest panorama sferyczna pozwalająca rozglądać się użytkownikowi dookoła o $360^{\circ}$ oraz o $180^{\circ} \mathrm{W}$ 
pionie. Dzięki temu na zdjęciu widać miejsce, w którym znajdował się fotograf oraz jego otoczenie (Gajewski 2011).

Twórcy wirtualnych spacerów z powodzeniem wykorzystują technikę interaktywnych panoram $360^{\circ}$, czyniąc $\mathrm{z}$ nich bardzo przydatne medium informacyjne dające możliwość przemieszczania się między zdjęciami panoramicznymi. Odbiorca uzyskuje wówczas dokładną i realistyczną w odbiorze formę zwiedzania danej przestrzeni bez konieczności fizycznej obecności w danym miejscu. Stosowanie rozwiązań multimedialnych umożliwia dołączanie kolejnych multimediów. Wirtualny spacer można wzbogacić o treści tekstowe, zdjęcia, filmy, podkłady muzyczne i głosowe, mapy, plany sytuacyjne czy okulary VR.

Użycie wspomnianych rozwiązań w prezentacjach multimedialnych typu wirtualna wycieczka powinno być łatwe i możliwie intuicyjne. W miarę jak rośnie złożoność systemów komputerowych, poszerza się ich funkcjonalność, która musi odpowiadać rosnącym potrzebom internautów. Należy zatem stosować takie rozwiązania w zakresie interakcji człowiek-komputer, aby systemy komputerowe mogły być z łatwością obsługiwane przez użytkowników i realizowały postawione przed nimi wymagania. Rozwiązaniem tym jest interfejs użytkownika, czyli część urządzenia i działającego na nim oprogramowania, którą człowiek może zobaczyć, usłyszeć, dotknąć, mówić do niego lub zrozumieć w inny sposób, a także nim kierować (Galitz 2002).

W kontekście wirtualnych spacerów będzie to interfejs graficzny, zapewniający komunikowanie się człowieka z oprogramowaniem komputera za pomocą obiektów wyświetlanych na monitorze w trybie graficznym. Przy wprowadzaniu danych korzysta się z klawiatury i myszy. Graficzny interfejs użytkownika zwykle zawiera menu, czyli wyświetlane w określonym miejscu ekranu polecenia, które można wybrać za pomocą myszy. Ponadto na ekranie znajdują się symbole (ikony) oznaczające obiekty. Interfejs graficzny ma też okna wyświetlane na ekranie lub na jego części, które mogą być niezależnie rozmieszczane i przesuwane oraz funkcje dialogowe, np. zapytanie o potwierdzenie wydanego polecenia lub wyświetlenie komunikatu (<https://encyklopedia.pwn.pl/haslo/ graficzny-interfejs-uzytkownika;3907397.html> [dostęp: 4.12.2018]).

Ważne znaczenie dla internauty ma jakość ergonomiczna interfejsu graficznego, która wpływa na postrzeganą przez niego użyteczność systemu. Ergonomia interfejsu decyduje o łatwości obsługi systemu, wygodzie dostępu do funkcji, wpływa na postrzeganą użyteczność produktu, a także na dopasowanie funkcjonalności systemu do potrzeb (Sikorski 2006).

Dobrze zaprojektowany graficzny interfejs, jak wynika z powyższej definicji, powinien być podzielony na obszary przeznaczone do różnych celów oraz powinien b yć czytelny dla użytkownika, który łatwo może orientować się, gdzie się znajdują i co oznaczają prezentowane informacje. Ważną cechą interfejsu jest estetyka. Związana jest ona z symetrią, spójnością, regularnością, porządkiem 
i złożonością. Prawidłowe rozmieszczenie informacji pomaga zrozumieć je i zapamiętać. Są one wówczas przyswajane w krótszym czasie i zapamiętywane na dłużej. Zły interfejs przeszkadza w komunikacji z użytkownikiem (Ngo 2001). Według Kuchty [b.d.] graficzny interfejs powinien uwzględniać doświadczenie użytkownika, tzn. zarówno łatwość posługiwania się dla początkujących, jak i oferować funkcje dla doświadczonych użytkowników. Interfejs powinien być też spójny, co ułatwia użytkownikowi przewidywanie skutków podejmowanych przez niego działań przy jednoczesnym minimalizowaniu wysiłku. Interfejs prowadzi użytkownika przez program tak, by liczba kroków wiodących do osiągnięcia celu była jak najmniejsza. Wszystkie powyżej wskazane elementy interfejsu składają się na jego funkcjonalność rozumianą jako zakres dostępnych funkcji lub opcji. W odniesieniu do serwisów dostępnych w Internecie wyróżnia się następujące czynniki funkcjonalności (Nielsen 2003):

1. intuicyjność - łatwość wykonania podstawowych zadań podczas pierwszego zetknięcia się z serwisem,

2. efektywność - szybkość realizowania zadań przez użytkowników, którzy już zapoznali się z interfejsem serwisu,

3. przyswajalność- szybkość przywracania biegłości w wykonywaniu zadań po dłuższej nieobecności w serwisie,

4. odporność na błędy - odporność na błędy użytkownika popełniane podczas pracy,

5. satysfakcja - poczucie zadowolenia odbiorcy podczas korzystania z serwisu. Współcześnie aplikacje sieciowe zapewniające zaawansowaną geowizualizację zapewniają odbiór przekazywanych treści dostosowany do potrzeb użytkownika. Podnosi to efektywność pracy z informacją geograficzną i wpływa na satysfakcję odbiorcy. Atrakcyjność wirtualnych spacerów wynika przede wszystkim z funkcjonalności serwisu, szybkości dostępu do informacji geograficznej za ich pośrednictwem, a także z różnorodności prezentowanych w nich treści.

Celem pracy jest charakterystyka graficznego interfejsu użytkownika i funkcjonalności aplikacji wirtualnych wycieczek na przykładzie serwisów QTVRPoland $<$ http://www.qtvr-poland.com/> oraz Wirtualny Kraj $<$ http://wirtualnykraj.pl/>.

Celem pośrednim jest wstępna ocena techniczna wybranych wirtualnych wycieczek umieszczonych w analizowanych serwisach. Ocenę wykonano za pomocą narzędzia Web Page Analizer - $0.98<\mathrm{http}$ ///www.websiteoptimization. com/services/analyze/> firmy Website Optimization.

Web Page Analyzer - 0.98 jest internetowym narzędziem, które umożliwia sprawdzenie strony WWW pod kątem jej budowy i poprawności. Wyniki analizy przedstawiane są $\mathrm{w}$ formie raportu online. Raport podzielony jest na dwie części. Pierwsza część to diagnoza strony zawierająca zestawienia tabelaryczne szczegółowych statystyk dotyczących m.in. statystyk globalnych, czasu pobierania, liczby zewnętrznych elementów czy wielkości nagłówków elementów strony 
(HTML, CSS itp.). Druga część raportu Analiza i zalecenia zawiera opis (np. „całkowity rozmiar obrazów” przekroczył X bajtów) wraz z zaleceniami, jak daną stronę zoptymalizować. Opis ten wykorzystuje kolor wraz z komentarzem (zielony - „gratulacje”, żółty - „uwaga”, czerwony - „ostrzeżenie”). Elementy, w których strona jest optymalnie zbudowana, oznaczone są kolorem zielonym, a te, na które należy zwrócić szczególną uwagę (możliwość poprawy - propozycja) oraz które wymagają zmiany kolorem odpowiednio: żółtym i czerwonym. Druga część raportu stanowi również gotową interpretację statystyk. W niniejszym artykule, w ramach oceny technicznej, zaprezentowano wyniki w taki sam sposób (kolor) jak w drugiej części omawianego raportu. Przyjęto także tę samą interpretację wyników (tabela w ocenie technicznej).

W przypadku wirtualnych wycieczek serwisu Wirtualny Kraj w artykule uwzględniono wyłącznie wersje Flash. Wirtualny Kraj oferuje również wycieczki w technologii HTML5. Wybór technologii Flash do analizy podyktowany był tym, że w serwisie QTVR-Poland wycieczki są wykonane we Flash (zachowanie porównywalności serwisów).

\section{INTERFEJS I FUNKCJONALNOŚĆ WIRTUALNYCH WYCIECZEK}

QTVR-Poland <http://www.qtvr-poland.com/> oferuje konstrukcję wirtualnej wycieczki opartej na zbiorze kilku powiązanych między sobą tematycznie

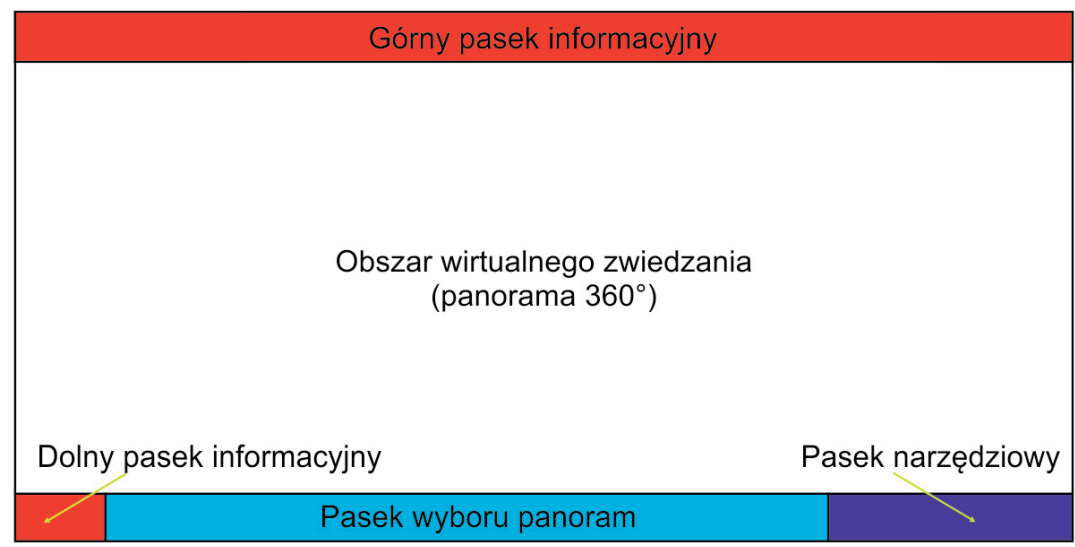

Ryc. 1. Budowa interfejsu wirtualnej wycieczki „Kraków nocą” w serwisie QTVR-Poland

Źródło: oprac. własne na podstawie <http://www.qtvr-poland.com/panoramas/339.html> [dostęp: 30.09.2018].

Fig. 1. Construction of the interface of a virtual tour „Kraków nocą” on QTVR-Poland website Source: own elaboration based on $<$ http://www.qtvr-poland.com/panoramas/339.html $>$ [access: 30.09 .2018$]$. 
panoram $360^{\circ}$ (Pilarska, Tomczykowska 2018). Interfejs użytkownika można podzielić na cztery zasadnicze paski (ryc. 1).

Górny pasek informacyjny zawiera nazwę wirtualnej wycieczki (prezentowanym obiekcie) wraz z lokalizacją na mapie Polski oraz logo i hasło projektu (strony internetowej QTVR-Poland), a dolny pasek informacyjny zawiera informację o autorze.

W ramach paska narzędziowego dostępne są następujące funkcje: „w okolicy”, „pełny ekran”, „,pomoc”, „,info” oraz „panoramy”. Po kliknięciu „,w okolicy" na środku obszaru wirtualnego zwiedzania wyświetla się mapa Polski (w podziale na województwa, na której zaznaczona jest lokalizacja obiektu przedstawionego w ramach wirtualnej wycieczki) wraz z wykazem (zbiorem linków) znajdujących się najbliżej wirtualnych wycieczek udostępnianych w ramach QTVR-Poland. Co ciekawe, podano również odległości w kilometrach. Dla wirtualnej wycieczki „Kraków nocą” wykaz ten zawiera dziewięć obiektów, m.in.: „Karków - stare miasto” $(0,08 \mathrm{~km})$, „Hotel Wawel” $(0,40 \mathrm{~km})$ czy „Kolegiata św. Anny - Kraków” (0,46 km). Dla wirtualnej wycieczki „Warszawskie Śródmieście” są to m.in.: „Pałac Nauki i Kultury w Warszawie” $(0,08 \mathrm{~km})$, „Pałac w Jabłonnej” (18,04 km), „Muzeum Witolda Gombrowicza” $(78,57 \mathrm{~km})$.

Dla funkcji „info” w lewej części aplikacji wyświetlana jest charakterystyka obszaru przedstawionego w ramach wirtualnego zwiedzania (ryc. 2). Przykładowo dla wycieczki „Kraków nocą” jest to m.in. informacja o położeniu Krakowa oraz pełnionych przez to miasto funkcjach administracyjnych. Dla wycieczki „Warszawskie Śródmieście” zawarta jest m.in. informacja o granicach śródmieścia oraz informacja o Pałacu Kultury i Nauki. Nad charakterystyką znajduje się miejsce (okno), w ramach którego najprawdopodobniej ma być wyświetlana Mapa Google. Jednakże występuje błąd jej wyświetlania spowodowany tym, że wycieczki w analizowanym serwisie zostały opracowane w technologii Flash. Obecnie technologia ta nie jest wspierana. Google w 2017 r. m.in. przestało akceptować reklamy wykonane we Flash (Monotype, 2016). Obowiązującym standardem jest HTML5, które zapewnia natywne wsparcie m.in. wyświetlania grafiki wektorowej (format SVG) (Zbyrowska 2011).

Poruszanie się w ramach wirtualnej wycieczki odbywa się w „obszarze wirtualnego zwiedzania" (ryc. 2), za pomocą myszki i klawiatury (obracanie, oddalanie, przybliżanie, góra, dół). Przejście do innej panoramy w ramach wycieczki obywa się po kliknięciu w pasku narzędziowym przycisku „panoramy” i wyborze jednej z panoram. Dla „Krakowa nocą” oraz „Warszawskiego Śródmieścia” przewidziano po sześć panoram, np. „Panorama Śródmieścia z Orco Tower” i „Teatr im. J. Słowackiego”.

Odmienną konstrukcję aplikacji oraz bardziej rozbudowaną funkcjonalność wirtualnej wycieczki oferuje Wirtualny Kraj <http://wirtualnykraj.pl>. Serwis proponuje wirtualne wycieczki w formie kompleksowych (multimedialnych) 


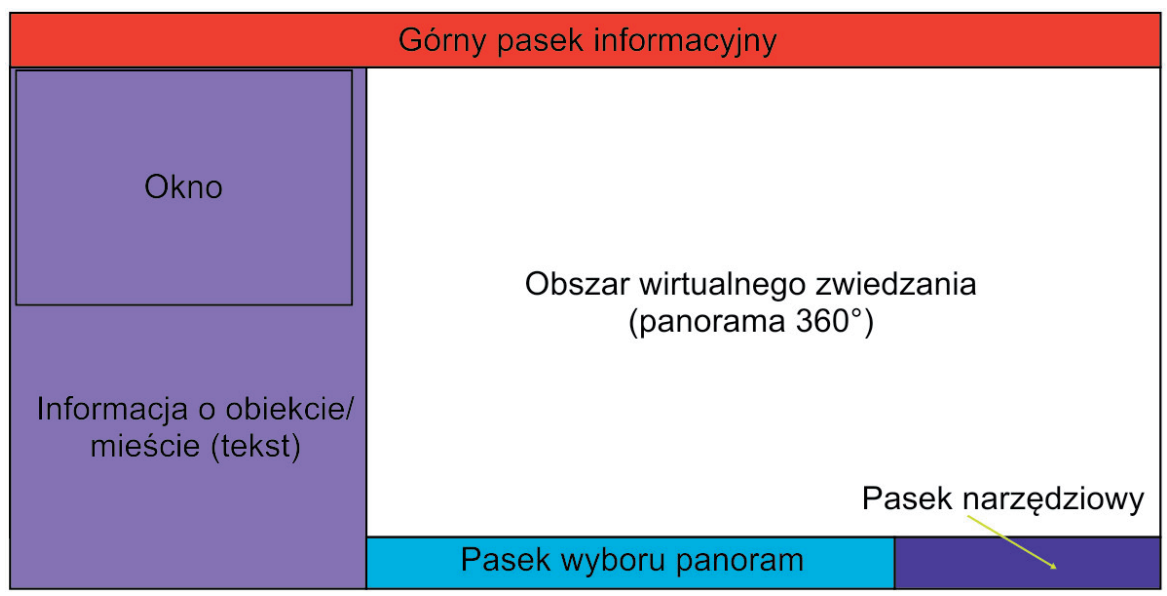

Ryc. 2. Interfejs po kliknięciu funkcji „info” w wirtualnej wycieczce „Kraków nocą” w serwisie QTVR-Poland

Źródło: oprac. własne na podstawie <http://www.qtvr-poland.com/panoramas/339.html> [dostęp: 30.09.2018].

Fig. 2. Interface after clicking the "info” function in a virtual tour „Kraków nocą" on QTVR-Poland website

Source: own elaboration based on $<$ http://www.qtvr-poland.com/panoramas/339.html > [access: 30.09 .2018 ].

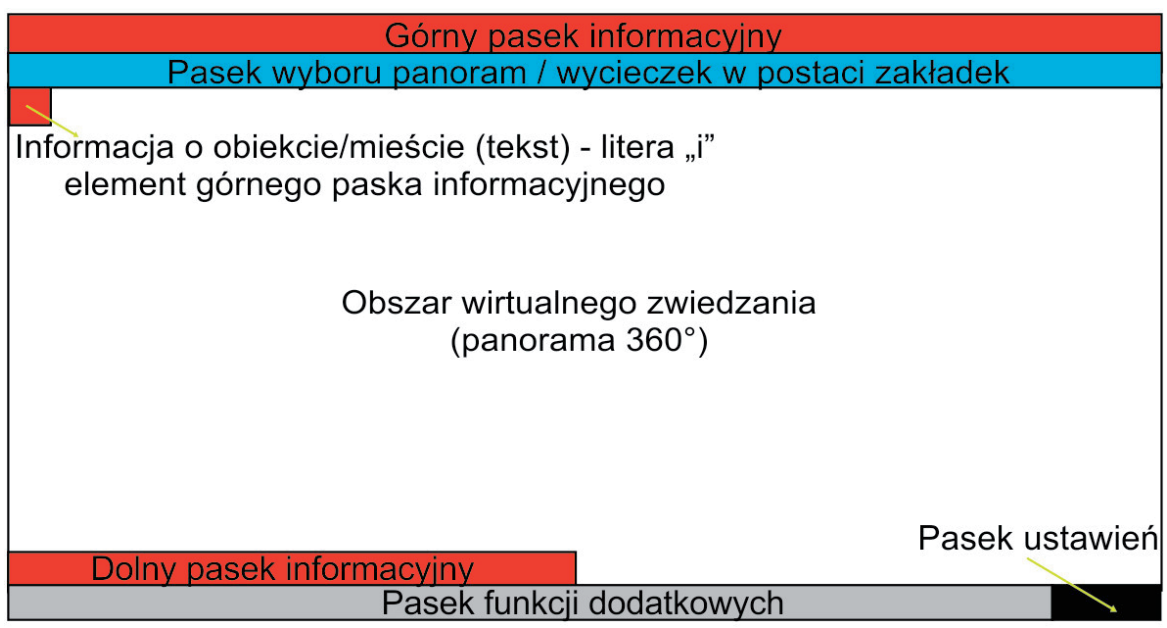

Ryc. 3. Budowa interfejsu wirtualnej wycieczki „Sejm Rzeczypospolitej Polskiej” w serwisie Wirtualny Kraj

Źródło: oprac. własne na podstawie <http://sejm.wkraj.pl/\#/38690/0> [dostęp: 12.11.2018].

Fig. 3. Construction of the interface of a virtual tour „Sejm Rzeczypospolitej Polskiej” on Wirtualny Kraj website

Source: own elaboration based on $<$ http://sejm.wkraj.pl/\#/38690/0> [access: 12.11.2018]. 
aplikacji (Pilarska, Tomczykowska 2018). Interfejs użytkownika można podzielić na pięć zasadniczych pasków (ryc. 3).

Górny pasek informacyjny zawiera dane dotyczące aktywnej wersji językowej. Liczba wersji językowych jest zróżnicowana w zależności od miasta. Dla wycieczki „Kraków. Miasto Królów Polskich” oraz „Miasto Stołeczne Warszawa" przewidziano wyłącznie polską wersję interfejsu, natomiast dla wycieczki „Sejm Rzeczypospolitej Polski” wersję niemiecką, angielską, francuską, polską i rosyjską. Ponadto pasek ten zawiera informacje na temat tego co jest oglądane, polubienia na portalu Facebook oraz autora/właściciela aplikacji (sformułowanie: „,wirtualne spacery i wycieczki panoramiczne zapewnia: wirtualnykraj.pl”), a także tekst - opis obiektu lub miasta (litera „i”). Dolny pasek informacyjny zawiera informacje dotyczące: nazwy miasta, instytucji lub obiektu, województwa, adresu, liczby wyświetleń, ID miejsca oraz daty wykonania aplikacji.

Trzecim paskiem jest pasek wyboru panoram i wycieczek (zakładki tematyczne). Poszczególne wydzielone zakładki (odmienne dla każdej wycieczki) umożliwiają rozpoczęcie wirtualnego spaceru od wybranego obiektu lub zawierają zbiór panoram (galerię) dla wydzielonych w zakładkach kategorii, np. dla wycieczki „Miasto Stołeczne Warszawa” są to: „,spacery”, „zamki i pałace”, „różne” (m.in. „mosty”, „Cytadela”, „Park Fontann”). Również w zakładkach w pasku wyboru znajdują się obiekty, dla których opracowano odrębne wirtualne spacery. Po kliknięciu na nazwę obiektu następuje automatyczne przekierowanie do aplikacji dla danego obiektu. Za przykład może posłużyć wycieczka „Kraków. Miasto Królów Polskich”, dla której wyodrębniono zakładki: „projekty w Krakowie” oraz „okolice Krakowa”. W ramach tych zakładek następuje przeniesienie użytkownika do odrębnych wycieczek, takich jak: „Muzeum Archeologiczne w Krakowie”, „Pałac Arcybiskupów w Krakowie”, „Sanktuarium Maryjno-Pasyjne w Kalwarii Zebrzydowskiej” czy „Zamek w Nowym Wiśniczu”. Zakładka „okolice Krakowa” zawiera również informacje o odległościach od Krakowa, np. „Wieliczka (13 km)”, „Rytro (129 km)”.

Czwarty pasek obejmuje funkcje dodatkowe. Zawiera on następujące elementy podstawowe: „pomoc”, ,nowości”, „,komentarze”, „pocztówka”, „miniaturki” (są to miniaturki panoram), „szybka prezentacja”, „kod QR”, „mapa”, „warto zobaczyć” oraz „szukaj”.

W zakres omawianego paska wchodzą dwie funkcje charakterystyczne dla internetowych mediów społecznościowych: „komentarze”, dzięki której można dodać własny komentarz na temat wirtualnej wycieczki lub przeczytać opinie innych użytkowników oraz „pocztówka”. Wycieczkę „Kraków. Miasto Królów Polskich” skomentowano 18 razy (stan na 26.11.2018), „Miasto Stołeczne Warszawa” - brak komentarzy, a dla wycieczki „Sejm Rzeczypospolitej Polskiej” wyświetlony zostaje komunikat: „W tym miejscu możliwość komentowania została wyłączona". W ,pocztówce” wybiera się interesującą nas panoramę, a następnie podaje swój adres e-mail, adres odbiorcy i treść wiadomości. 
Funkcja „mapa” zawiera szczegółową inwentaryzację obiektów turystycznych (z oznaczeniem i wywołaniem przez kliknięcie panoram) obiektów użyteczności publicznej oraz informację o lokalizacji użytkownika wirtualnej wycieczki w przestrzeni miasta. Mapa ma suwak powiększenia/zmniejszenia, możliwość zmiany podkładu kartograficznego na podkład satelitarny (oba należące do OpenStreetMap), a także informacje o współrzędnych - nazwanych w aplikacji „Współrzędne GPS”. Należy podkreślić, iż przeglądanie mapy nie ogranicza się wyłącznie do małego kwadratowego wydzielenia znajdującego się w lewej części aplikacji. Mapę można powiększyć do obszaru wirtualnego zwiedzania.

Interesujące z punktu widzenia potencjalnego turysty wydają się także funkcje: „szybka prezentacja” oraz „warto zobaczyć”. W ramach „,szybkiej prezentacji" uzyskuje się automatycznie przewijany przegląd wszystkich panoram dostępnych w ramach danej wycieczki tematycznej wraz z jej współrzędnymi geograficznymi, nazwą panoramy oraz informacją o liczbie panoram. „Warto zobaczyć" zawiera przegląd wszystkich aplikacji wirtualnych wycieczek w zakresie „ciekawe miejsca w pobliżu”, w podziale na 20 kategorii, m.in.: „ciekawostki”, ,obiekty sakralne”, „powiat”, „wyciąg narciarski” czy „,adny widok”. Dla wycieczki „Miasto Stołeczne Warszawa” liczba miejsc wynosi 0, dla „Sejm Rzeczypospolitej Polskiej” 140, a dla „Kraków. Miasto Królów Polskich” 126.

Ostatnim paskiem wydzielonym $\mathrm{w}$ analizowanym interfejsie jest pasek ustawień. Zawiera opcję ustawienia jakości wyświetlanej aplikacji („ultra”, „wysoka”, „średnia”, „niska”), włączenia/wyłączenia „podpowiedzi głosowych”, włączenia/wyłączenia „dźwięku” oraz opcję ,pełny ekran”.

Wyżej scharakteryzowane poszczególne elementy interfejsu służą przede wszystkim skokowej eksploracji przestrzeni turystycznej. Efekt wirtualnego zwiedzania uzyskuje się przez kliknięcie przycisku „start”. Otworzona zostaje panorama, która jest w danej aplikacji startową (ryc. 4). Dla wycieczek „Kraków. Miasto Królów Polskich” oraz „Stołeczne Miasto Warszawa” są to widoki tych miast z lotu ptaka, a dla wycieczki „Sejm Rzeczypospolitej Polskiej” jest to miejsce (widok) „przed głównym wejściem do Sejmu Rzeczypospolitej Polskiej”. Podobnie jak w przypadku otwarcia aplikacji w obszarze wirtualnego zwiedzania (lewy, górny narożnik) wyświetla się literka „i” (informacja). W przypadku wycieczki „Miasto Stołeczne Warszawa” po kliknięciu wyświetla się informacja o historii inwestycji związanych z wodociągami, a dla wycieczki „Sejm Rzeczypospolitej Polskiej” jest to informacja o pełnionej funkcji wejścia głównego do Sejmu. W ramach panoramy startowej pozostają widoczne i aktywne główne paski interfejsu (ryc. 4).

Zwiedzanie może być wykonywane na sześć sposobów. Pierwszy jest związany z opcją , szukaj”. Po kliknięciu wyświetla pole wyszukiwania wraz z opcją wyszukania w ramach uruchomionej wirtualnej wycieczki lub strony $<$ wirtualnykraj.pl>. Przykładowo wpisując „Wawel” (w „Kraków. Miasto Królów Polskich"), otrzymuje się listę panoram, wśród których należy wymienić m.in. 


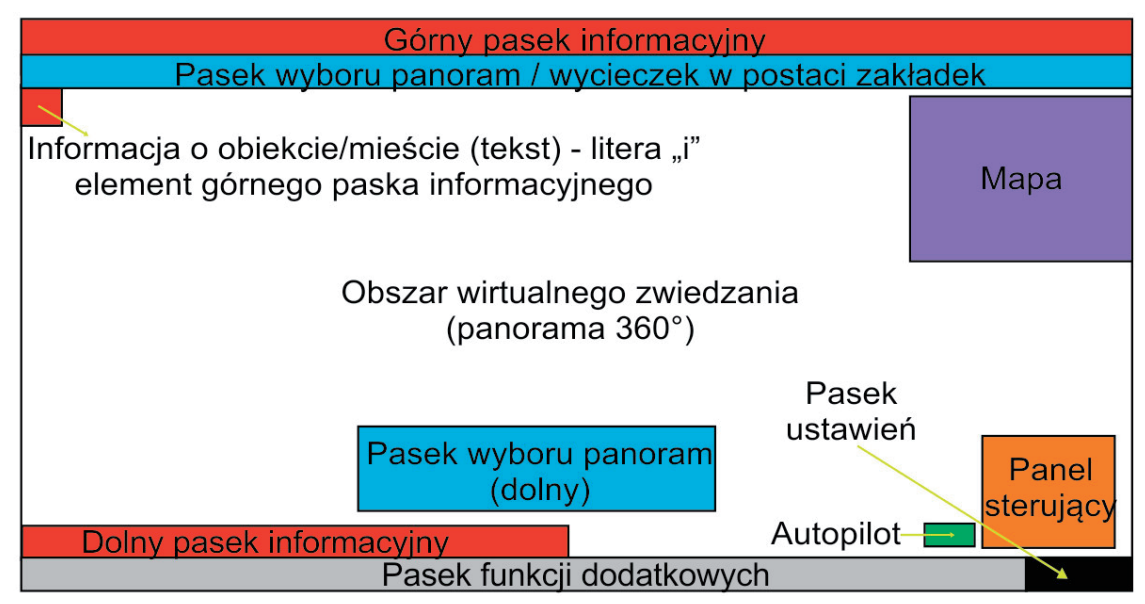

Ryc. 4. Początek zwiedzania w wirtualnej wycieczce „Sejm Rzeczypospolitej Polskiej” w serwisie Wirtualny Kraj

Źródło: oprac. własne na podstawie <http://sejm.wkraj.pl/\#/38690/0> [dostęp: 12.11.2018].

Fig. 4. The beginning of the sightseeing in a virtual trip „Sejm Rzeczypospolitej Polskiej” on Wirtualny Kraj website

Source: own elaboration based on $<$ http://sejm.wkraj.pl/\#/38690/0> [access: 12.11.2018].

panoramy pt.: „Smok Wawelski”, „Makieta kościołów świętych Piotra i Pawła oraz świętego Andrzeja” czy „Miejsce: Wawel - Brama Wazów”.

Drugim sposobem jest wybranie miniaturki panoramy wyświetlanej u dołu obszaru wirtualnego zwiedzania lub przez wybranie miniaturki na mapie nawigacyjnej i inwentaryzacyjnej albo na widoku miasta $\mathrm{z}$ lotu ptaka na panoramie startowej. Ponadto w ramach obszaru wirtualnego zwiedzania można posługiwać się ikonami podwójnych strzałek (przemieszczanie się do kolejnych lokalizacji w mieście). Jest to trzeci sposób odbywania wirtualnego zwiedzania.

Po danej panoramie poruszanie następuje za pomocą myszki w ramach opcji „podążaj za kursorem” lub „przeciągnij i upuść” (sposób czwarty). Tradycyjnie sterowanie kursorem następuje przez klikanie kursorem myszy lewo/prawo, góra/dół, rolką myszki - przybliż/oddal. Alternatywnie można poruszać się w ramach obszaru wirtualnego zwiedzania za pomocą panelu sterującego znajdującego się w dolnym lewym rogu okna (nawigacja strzałkami jako sposób piąty). Dodatkowo w panelu tym znajduje się opcja ,cofnij” (do poprzedniej panoramy), „przybliż”, „oddal” oraz wspomniany wybór sterowania: „przeciągnij i upuść" lub „podążaj za kursorem".

Opcja ,autopilot” jest ostatnim sposobem zwiedzania przestrzeni danego miasta lub obiektu. Jest to narzucona trasa zwiedzania (czasami z narracją, przykład: wycieczka „Miasto Kraków”- <http://www.krakow.pl/spacer>). Jakakolwiek zmiana tejże trasy jest tylko możliwa przez zatrzymanie ,autopilota" i zwiedzanie opisanymi wcześniej sposobami. Po wyborze innej panoramy 
można wznowić zwiedzanie za pomocą ,autopilota”. Pod literą ,„i” podczas włączonej opcji ,autopilota” wyświetlana jest nazwa aktualnie zwiedzanej panoramy. Użytkownik sam decyduje o zakończeniu zwiedzania przez kliknięcie w pasku wyboru zakładki ,,początek”/,start”.

\section{OCENA TECHNICZNA WIRTUALNYCH WYCIECZEK}

Raporty cząstkowe wygenerowane przez narzędzie Web Page Analyzer 0.98 wskazują, że optymalną budową oraz poprawnością strony internetowej (w ramach której wycieczka jest udostępniana) charakteryzują się wycieczki w serwisie QTVR-Poland (dominujący kolor zielony w raportach). Jedynie dla

Tabela 1. Ocena techniczna stron internetowych wirtualnych wycieczek

Table 1. Technical evaluation of virtual tours websites

\begin{tabular}{llcc}
\hline & & QTVR -Poland & Wirtualny Kraj \\
\cline { 2 - 4 } Kategorie według Web Page Analyzer - 0.98 & 1 & 2 & 5 \\
& & \multicolumn{2}{c}{$\begin{array}{c}\text { kolory według } \\
\text { Web Page Analyzer - } 0.98\end{array}$} \\
\cline { 2 - 4 } Całkowita liczba plików HTML & & \\
Całkowita liczba obiektów (wraz z HTML) \\
Całkowita liczba obrazów \\
Całkowita liczba zewnętrznych plików CSS \\
Całkowita wielkość strony \\
Całkowita liczba zewnętrznych plików skryptów \\
Całkowity rozmiar HTML \\
Całkowity rozmiar obrazów \\
Całkowity rozmiar zewnętrznych plików skryptów \\
Całkowity rozmiar zewnętrznych multimediów
\end{tabular}

Objaśnienia: analizowane wycieczki: 1 - „Muzeum Powstania Warszawskiego”, 2 - „Kraków nocą”, 3 - „Warszawskie Śródmieście”, 4 - „Miasto Stołeczne Warszawa”, 5 - „Kraków. Miasto Królów Polskich”, 6 - „Sejm Rzeczypospolitej Polskiej”.

Oznaczenia kolorów według Web Page Analyzer - 0.98: zielony - ,gratulacje”, żółty - „uwaga”, czerwony - „ostrzeżenie”.

Źródło: oprac. własne na podstawie raportów cząstkowych wygenerowanych przez: $<$ http://www. websiteoptimization.com/services/analyze $>$ (Web Page Analyzer - 0.98) dla stron: $<$ http://www.qtvrpoland.com/panoramas/327.html >, <http://www.qtvr-poland.com/panoramas/339.html >, <http://www. qtvr-poland.com/panoramas/527.html $>,<$ http://warszawa.wkraj.pl/index.php?\&pass=1\#/58121/0>, $<$ http://krakow.wkraj.pl/index.php?\&pass=1\#/64704/0>, <http://sejm.wkraj.pl/\#/38690/0> [dostęp: 20.11.2018].

Source: own elaboration based on partial reports generated by: $<\mathrm{http}: / / \mathrm{www} . w e b s i t e o p t i m i z a t i o n$. com/services/analyze > (Web Page Analyzer - 0.98) for websites: $<$ http://www.qtvr-poland.com/ panoramas/327.html>, <http://www.qtvr-poland.com/panoramas/339.html>, <http://www.qtvr-poland. com/panoramas/527.html>, <http://warszawa.wkraj.pl/index.php?\&pass=1\#/58121/0>, <http://krakow. wkraj.pl/index.php?\&pass $=1 \# / 64704 / 0>,<$ http://sejm.wkraj.pl/\#/38690/0 $>$ [access: 20.11.2018]. 
wycieczki „Kraków nocą” odnotowano uwagę dotyczącą kategorii „całkowity rozmiar obrazów" (tab. 1). Dotyczyła ona przekroczenia rozmiaru 50000 bajtów.

W serwisie Wirtualny Kraj na szczególną uwagę zasługują dwie kategorie związane z plikami skryptów. Ostrzeżenia dotyczące kategorii „całkowity rozmiar zewnętrznych plików skryptów" dotyczą przekroczenia 20000 bajtów, a w przypadku kategorii „całkowita liczba zewnętrznych plików skryptów” występowania trzech plików (zalecane wg raportu Web Page Analyzer - 0.98, jeden lub dwa pliki).

\section{PODSUMOWANIE}

Współcześnie rozwiązania technologiczne pozwalają na zaawansowaną i ciekawą prezentację danych geoprzestrzennych. Ciągłe doskonalenie funkcjonalności i troska o ergonomię interfejsów użytkownika poprawiają odbiór przekazywanych informacji z jednoczesną dbałością o zindywidualizowane potrzeby odbiorcy. Wpływa to na wzrost efektywności pracy z informacją geograficzną i zapewnia większą satysfakcję użytkownikom. Prezentacje multimedialne $\mathrm{w}$ formie wirtualnych spacerów swoją atrakcyjność zawdzięczają przed wszystkim funkcjonalności samego medium oraz mnogości i szybkości dostępu do informacji geograficznej uzyskiwanych za ich pośrednictwem.

W Internecie działają strony internetowe, których celem jest prezentacja wirtualnych wycieczek po Polsce. W pracy przedstawiono dwa z nich - QTVR Poland oraz Wirtualny Kraj. Zwrócono uwagę na najważniejsze różnice w budowie interfejsu użytkownika tych portali. Omówiono ich funkcjonalność i dokonano oceny technicznej serwisów. Zwrócono uwagę na języki, w których publikowane są opisy wirtualnych wycieczek.

Prezentacje multimedialne w formie wirtualnych wycieczek stanowią interesującą formę wirtualnej penetracji przestrzeni turystycznej miast. Taka forma przedstawiania danych przestrzennych w Internecie może przełożyć się na rozbudzenie ciekawości turystycznej i zaowocować odbywaniem realnych podróży. O tym, na ile dana wycieczka wirtualna może zainteresować odbiorcę, stanowi interfejs portalu, na którym została opublikowana. Łatwość i szybkość dotarcia do danych geograficznych, a także płynność przemieszczania się po trasie wirtualnego spaceru, przy jednoczesnym zapewnieniu optymalnej liczby informacji o zwiedzanym obiekcie, ma wpływ na zainteresowanie odbiorców. Podsumowując, należy dążyć do zapewnienia możliwie wysokiej funkcjonalności, ergonomiczności i intuicyjności obsługi graficznego interfejsu użytkownika celem zwiększenia liczby użytkowników. Warto także, by interfejs był nie tylko graficzny. Może być także obsługiwany za pomocą wzroku lub gestów w przypadku urządzeń mobilnych typu VR i AR. 


\section{LITERATURA}

Czyńska K., 2006: Metody kształtowania wspótczesnej sylwety miasta na przykładzie panoramy Szczecina. Wykorzystanie wirtualnych modeli miast $w$ monitoringu i symulacji panoram [pr. doktorska], <http://www.dbc.wroc.pl/Content/1710/metody_ksztaltowania.pdf> [dostęp: 12.09.2018].

Gajewski Ł., 2011: Analiza możliwości wykorzystania technologii informacyjnych do tworzenia internetowych wirtualnych spacerów po mieście Biała Podlaska, Zesz. Nauk. WSInf, $10,1,27-45$.

Galitz W.O., 2002: The Essentials Guide to User Interface Design, John Wiley \& Sons Inc., New York, 15.

Internetowy leksykon geomatyczny, 2011a: < https://www.ptip.info/LMB/SPO $\%$ C5\%81ECZE\%C5\%83STWO-GEOINFORMACYJNE]> [dostęp: 29.11.2018].

Internetowy leksykon geomatyczny, 2011b: <https://www.ptip.info/LMB/GEOINFORMACJA> [dostęp: 29.11.2018].

Kuchta J. [b.d.]: Projektowanie interfejsu uzytkownika, <https://docplayer.pl/35890185-Inzynieria-oprogramowania-jaroslaw-kuchta-projektowanie-interfejsu-uzytkownika-zasadyogolne.html> [dostęp: 10.09.2018].

Liszewski S., 2005: Przestrzeń turystyczna w ujęciu przedmiotowym. Przyczynek do dyskusji o przestrzeni geografii, [w:] W. Maik, K. Rembowska, A. Suliborski (red.), Geografia jako nauka o przestrzeni, środowisku i krajobrazie. T. 1. Podstawowe idee i koncepcje w geografii, Łódzkie Tow. Nauk., Łódź.

Młynarczyk K., 2014: Wirtualne wycieczki - nowy wymiar turystyki, <http://www.bankier.pl/wiadomosc/Wirtualne-wycieczki-nowy-wymiar-turystyki-2161239.html> [dostęp: 3.09.2014].

Monotype, 2016: The End of Flash: Separating Fact from Fiction, <http://go.monotype.com/ rs/396-BOK-818/images/Monotype_eBook-The_End_of_Flash.pdf> [dostęp: 6.12.2018].

Nielsen J., 2003: Projektowanie funkcjonalnych serwisów internetowych, Helion, Gliwice.

Ngo D.C.L., 2001: Measuring the aesthetic elements of screen design, Displays, 22, 73-78.

Pilarska A., 2015: Zwrot ku informacji przestrzennej: o przestrzeniach kształtowania sie spoteczeństwa geoinformacyjnego w Internecie, Zesz. Nauk. Tow. Doktorantów UJ, Nauk. Społ., 11(2), 97-115.

Pilarska A., 2012: Wirtualna przestrzeń geoinformacyjna jako odzwierciedlenie przestrzeni geograficznej, [w:] A. Gese, M. Krzyżyński (red.), Książka streszczeń, II Kopernikańskie Sympozjum Studentów Nauk Przyrodniczych, I Edycja Ogólnopolska, Toruń, 57.

Pilarska A., Tomczykowska P., 2018: Virtual tourism space of cities, Journ. of Modern Sc., 38(3), 317-333, <https://doi.org/10.13166/jms/99215> [dostęp: 29.11.2018].

Sikorski M., 2006: Interfejs użytkownika: od pracy, przez emocje, do relacji, Unpublished paper presented at Interfejs użytkownika - Kansei w praktyce Conference, Warszawa 2006.

Tech Trends, 2017: The kinetic enterprises, $<$ https://businessinsider.com.pl/media/internet/ilu-polakow-korzysta-z-internetu-raport-deloitte/f0wn6q4> [dostęp: 12.09.2018].

Zbyrowska K., 2011: Porównanie technologii HTML5 i Flash, Zesz. Nauk. WSInf, 10, 1, 74-89.

\section{Źródła online}

<http://krakow.wkraj.pl/index.php?\&pass=1\#/64704/0> [dostęp: 20.11.2018].

$<$ http://sejm.wkraj.pl/\#/38690/0> [dostęp: 12.11.2018 oraz 20.11.2018].

$<$ http://warszawa.wkraj.pl/index.php?\&pass=1\#/58121/0> [dostęp: 20.11.2018]

$<$ http://wirtualnykraj.pl/> [dostęp: 30.09.2018, 12.11.2018 oraz 20.11.2018].

$<$ http://www.krakow.pl/spacer> [dostęp: 20.11.2018].

$<$ http://www.qtvr-poland.com/> [dostęp: 30.09.2018, 12.11.2018 oraz 20.11.2018]. 
$<$ http://www.qtvr-poland.com/panoramas/327.html> [dostęp: 20.11.2018].

$<$ http://www.qtvr-poland.com/panoramas/339.html> [dostęp: 30.09.2018 oraz 20.11.2018].

$<$ http://www.qtvr-poland.com/panoramas/527.html> [dostęp: 20.11.2018].

$<$ http://www.websiteoptimization.com/services/analyze> [dostęp: 20.11.2018].

$<$ https://encyklopedia.pwn.pl/haslo/graficzny-interfejs-uzytkownika;3907397.html> [dostęp: 4.12.2018]. 